\title{
POTENTIAL FISHING ZONES ESTIMATION BASED ON APPROACH OF AREA MATCHING BETWEEN THERMAL FRONT AND MESOTROPHIC AREA
}

\author{
ESTIMASI DAERAH POTENSI PENANGKAPAN IKAN BERDASARKAN \\ PENDEKATAN KESESUAIAN AREA THERMAL FRONT DAN AREA MESOTROPIK
}

\author{
Argo Galih Suhadha* \& Wikanti Asriningrum \\ Remote Sensing Application Center, LAPAN, Jakarta, 13710, Indonesia \\ *E-mail: argo.galih@lapan.go.id
}

\begin{abstract}
Research in Potential Fishing Zone (PFZ) has undergone many developments, including parameter suitability selection. The thermal front has become the primary parameter input of ZPPI (LAPAN's PFZ). The accuracy of the thermal front parameter to predict PFZ cannot be known with certainty because of the radius between ZPPI with fishing areas, so it is necessary to develop parameters to support the thermal front. The thermal front described the meeting area of two water masses with different temperature characteristics associated with high nutrients (chlorophyll-a) and indicate an upwelling's appearance. This study aims to determine ZPPI by approaching the thermal front and mesotrophic area's matching area (chlorophyll-a concentration $0.2-0.5 \mathrm{mg} / \mathrm{m} 3$ ). Chlorophyll-a and sea surface temperature data for thermal fronts detection are derived from Aqua MODIS satellite on Google Earth Engine (GEE). The matching area's approach between the thermal front and mesotrophic area is used in the analysis of ZPPI. The results show thermal front and mesotrophic area on WPPNRI 715 have a variation seasonally where December appears like the peak event. The two parameters are distributed evenly from coastal areas to high seas. This method generates thermal fronts that have more than $60.3 \%$ matching with the mesotrophic area where the amount is acceptable due to has more than 50\% amount of moderate ZPPI. The accuracy improvement in ZPPI both on the coast and open sea can be determined through this approach.
\end{abstract}

Keywords: GEE, PFZ, remote sensing, thermal front, mesotrophic area, WPPNRI-715

\begin{abstract}
ABSTRAK
Zona potensi penangkapan ikan (ZPPI) telah mengalami banyak pengembangan salah satunya adalah pemilihan kesesuaian parameter. Thermal front telah menjadi parameter utama dalam input informasi ZPPI LAPAN. Akurasi informasi thermal front yang digunakan sebagai input ZPPI tidak dapat diketahui dengan pasti signifikansinya karena faktor jarak informasi titik ZPPI terhadap lokasi tangkapan sehingga diperlukan pengembangan parameter untuk mendukung informasi thermal front tersebut. Thermal front merupakan daerah pertemuan dua massa air yang memiliki karakteristik suhu yang berbeda dan mengindikasikan kemunculan upwelling. Penelitian ini bertujuan untuk menentukan daerah potensi penangkapan ikan dengan pendekatan kesesuaian area thermal front dengan area mesotropik (konsentrasi klorofil-a 0,2-0,5 $\mathrm{mg} / \mathrm{m}^{3}$ ). Data klorofil-a untuk deteksi area mesotropik dan suhu permukaan laut untuk thermal front berasal dari satelit Aqua MODIS di Google Earth Engine (GEE). Metode kesesuaian thermal front terhadap area mesotropik digunakan dalam analisis daerah potensi penangkapan ikan. Hasil penelitian menunjukkan bahwa thermal front dan area mesotropik di WPPNRI 715 memiliki variasi terhadap musim, dengan bulan Desember sebagai puncak kejadian. Kedua parameter tersebut terdistribusi secara merata mulai dari area pesisir hingga laut lepas. Dari metode ini didapatkan thermal front yang memiliki kesesuaian area (bertampalan) terhadap area mesotropik sebesar 60,3\%. Selain itu kelas ZPPI dengan tingkat kepercayaan tinggi memiliki jumlah lebih dari 50\% ZPPI moderate, dimana jumlah tersebut sesuai ambang batas yang dapat diterima. Sehingga peningkatan akurasi lokasi ZPPI baik di pesisir maupun laut lepas dapat ditentukan melalui pendekatan ini.
\end{abstract}

Kata kunci: area mesotropik, GEE, pengindraan jauh, thermal front, WPPNRI-715, ZPPI 


\section{INTRODUCTION}

In Indonesia, potential fishing zones information has been produced daily by LAPAN using the thermal front as the main parameter extracted from sea surface temperature from remote sensing imagery (Hamzah et al., 2014; Harsanugraha et al., 2014). Thermal front is known as the meeting area of two water masses which has a significant difference in sea surface temperature and has an important role for both physical and biological oceanography (Jatisworo \& Murdimanto, 2013; Podestá et al., 1993). Thermal front is used to predict potential fishing zones because it well known for upwelling and has a high primary production location with high chlorophyll contents associated with a large stock of phytoplankton (Reese et al., 2011). On the other hand, Podesta et al. (1993) stated that thermal front only has a significant association when correlated with elevated Cup per Unit Equals (CPUEs) of 50 fish per 1000 hooks where only represent $5-6 \%$ of the set. This is supported by Harsanugraha et al. (2014) where LAPAN's PFZ has an accuracy of up to $80.5 \%$ when within a fishing radius of 10 and 20 nautical miles (NM).

Research on Potential Fishing Zones (PFZ) is still growing, where many parameters have been used. As the well respond of fishes with changes in temperature and congregate around the upwelling makes potential fishing zones using thermal front have been developed in Indonesian water with $0.5^{\circ} \mathrm{C}$ as a gradient threshold (Hamzah et al., 2014; Harsanugraha et al., 2014; Jatisworo \& Murdimanto, 2013; Jishad et al., 2019), water fertility can be seen from the distribution of chlorophyll-a concentration also used as parameters to predict potential fishing zones with $80 \%$ success effectiveness where the peak harvest of tuna usually appears when chlorophyll-a levels are high (Nurdin et al., 2017; Syah et al., 2020; and
Zainuddin et al., 2006). The chlorophyll in high concentrations mostly associated with cool waters and its elevated structures are associated with ocean thermal front (Wijesekera et al., 2016). Furthermore, Sea Surface Height (SSH) spatial distribution indicates that its frontal regions (among cold and warm eddies) have Bigeye Tuna abundant catches (Lumban-Gaol et al., 2015).

Water fertility associated with the tropic status ranging from oligotrophic which has the lowest amount of biological productivity and quite good water quality, mesotrophic which has moderate biological productivity and quite a water quality, and eutrophic which has the highest biological activity and poor water quality. Furthermore, trophic status also calculated using more parameters such as Secchi depth, total Phosphorus, dissolved oxygen, and other nutrient parameters (El-Serehy et al., 2018; Wen et al., 2020). Mesotrophic are potential areas to be used as PFZ, in some locations (north-western North Pacific, archipelagic waters of Spermonde), where higher fish catches are found in the mesotrophic area with a concentration range of $0.2-0.5 \mathrm{mg} / \mathrm{m}^{3}$ (Nurdin et al., 2017; Zainuddin et al., 2006). This region is also the potential area for floating net fishery (FNF) (Rustini et al., 2018).

WPPNRI (Indonesian fisheries area management) 715 has quite complex water characteristics where the waters are passed by two lanes of Indonesian Throughflow (ITF), namely western and eastern lines. The west line or main branch flows from the Pacific Ocean into the Sulawesi Sea to the Makassar Strait and then turns east into the Flores Sea and the Banda Sea (Gordon et al., 1994). The west line of ITF makes WPPNRI715 and around especially in Maluku Sea, Banda Sea, and the southern part of the Makassar Strait have warmer temperatures than other seawater all season. This statement supported by a significant maximum warming trend by this region 
compared to other regions of Indonesian water in the last 30 years (Iskandar et al., 2020). Meanwhile, the temperature condition of this condition was significantly induced by the La Niña events.

The eastern line enters from the Halmahera Sea and continues to the Seram Sea, but some returns to the Pacific Ocean via the Maluku Sea (Wyrtki, 1961). The oceanographic condition caused the fish stock to reach 121,330 tons/year, but the utilization only reached $35 \%$ of its optimum effort in 2011 (Suman et al., 2014).

The large stock of fish in Indonesia has not been accompanied by high accuracy information on Potential Fishing Zones. This condition makes research to determine the most appropriate parameters of potential fishing zones in Indonesia still discussed because of the complexity and dynamics of Indonesian waters. In this case, thermal front and mesotrophic area are the most appropriate parameter in determining pelagic fish habitat (Harsanugraha et al., 2014; Nurdin et al., 2017). In this paper, we provide a method to estimate PFZ locations with the approach of the matching area between thermal front and mesotrophic area to improve the accuracy of ZPPI information.

\section{RESEARCH METHODS}

\subsection{Study Area}

The study area is located in $3^{\circ} \mathrm{U}-6^{\circ} \mathrm{S}$ and $120^{\circ}-135^{\circ} \mathrm{E}$ (Figure 1). WPPNRI 715 includes Tomini Bay, Maluku Sea, Seram Sea, and Berau Bay (Suman et al., 2014). Area selection is based on the analysis to be carried out, where is to analyze potential fishing areas based on thermal front and chlorophyll-a parameters. The study area has quite complex water characteristics both at the surface and the bottom of the water.

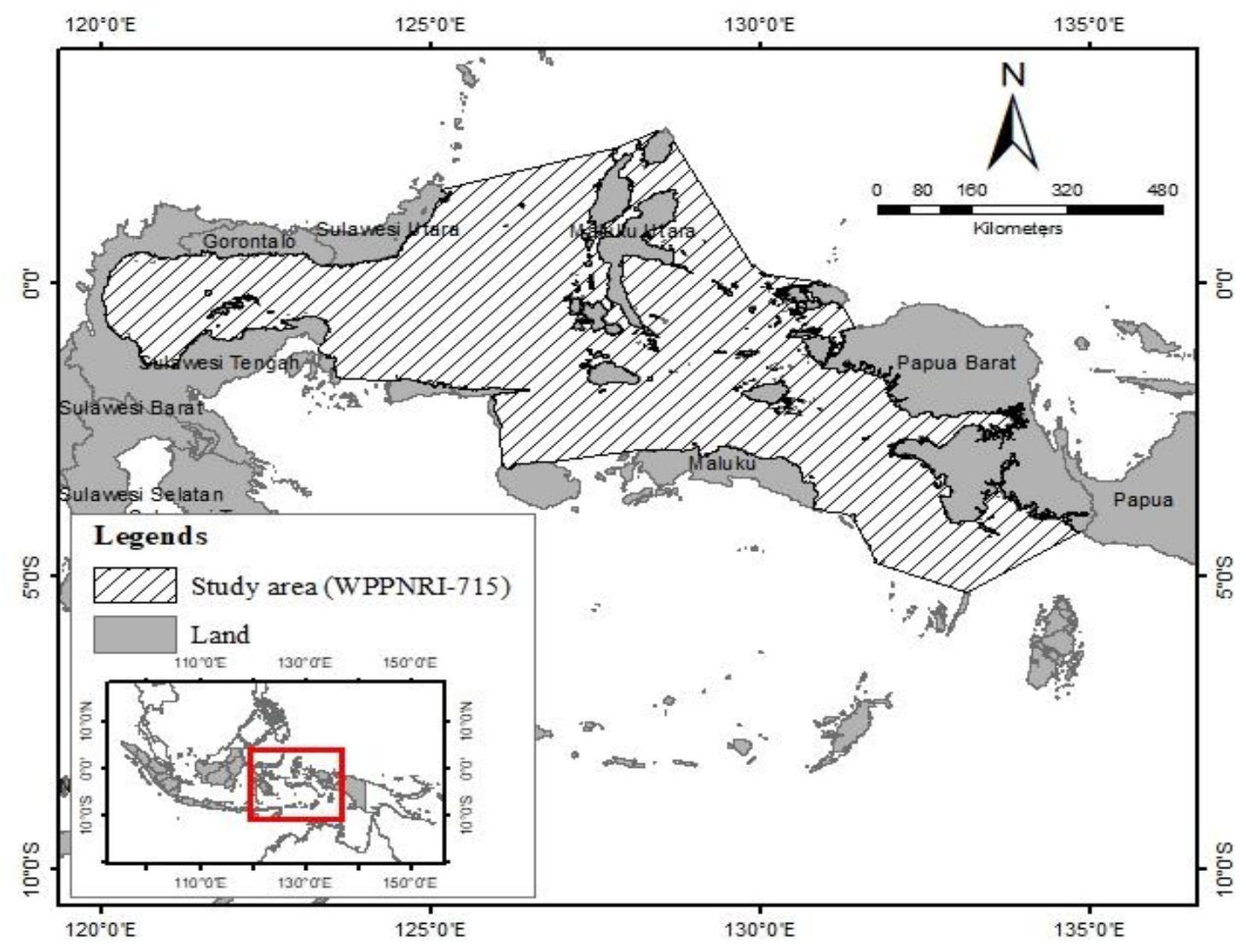

Figure 1. Study area. 


\subsection{Data Collection}

The data used in this study area are sea surface temperature (SST) and chlorophyll-a data from level-3 Aqua Moderate Resolution Imaging Spectroradiometer (MODIS) satellite imagery with a spatial resolution of $500 \mathrm{~m}$. Level-3 data are level 2 data collected and packaged in a day, eight days, one month, and one year. Image data is obtained from the Google Earth Engine (GEE) platform, which is a cloudbased platform for planetary-scale environmental data analysis that used computational infrastructure optimized for geospatial data and has a large repository of publicly available geospatial datasets including Aqua MODIS (Gorelick et al., 2017). GEE provides Aqua MODIS data with a delay time of around +/- 24 hours. Aqua MODIS data used is daily data with a period from January to December 2018 which eight data are taken each month with the selection based on the initial period of the recording month.

\subsection{Data Processing and Analyzing}

Data processing and analysis in this study is explained in the flowchart in Figure 2. The analysis consists of three parts, namely: identification of the thermal front, identification of chlorophyll-a, and determination of the ZPPI point. Thermal fronts are detected using the SIED (Single Image Edge Detection) algorithm by Cayula \& Cornillon (1992). This algorithm identifies thermal front using SST data input with a histogram algorithm on the frequency distribution of the values within image subsets and operated at 3 levels: picture level, window level, and local level (Cayula \& Cornillon, 1992; Chang \& Chornillon, 2015). The picture level determines the probability area that is affected by the cloud. Window level is used to determine the SST probability statistics in all windows. Locallevel concludes edge pixel statistics by considering neighboring pixels; at this level, the thermal front is obtained.

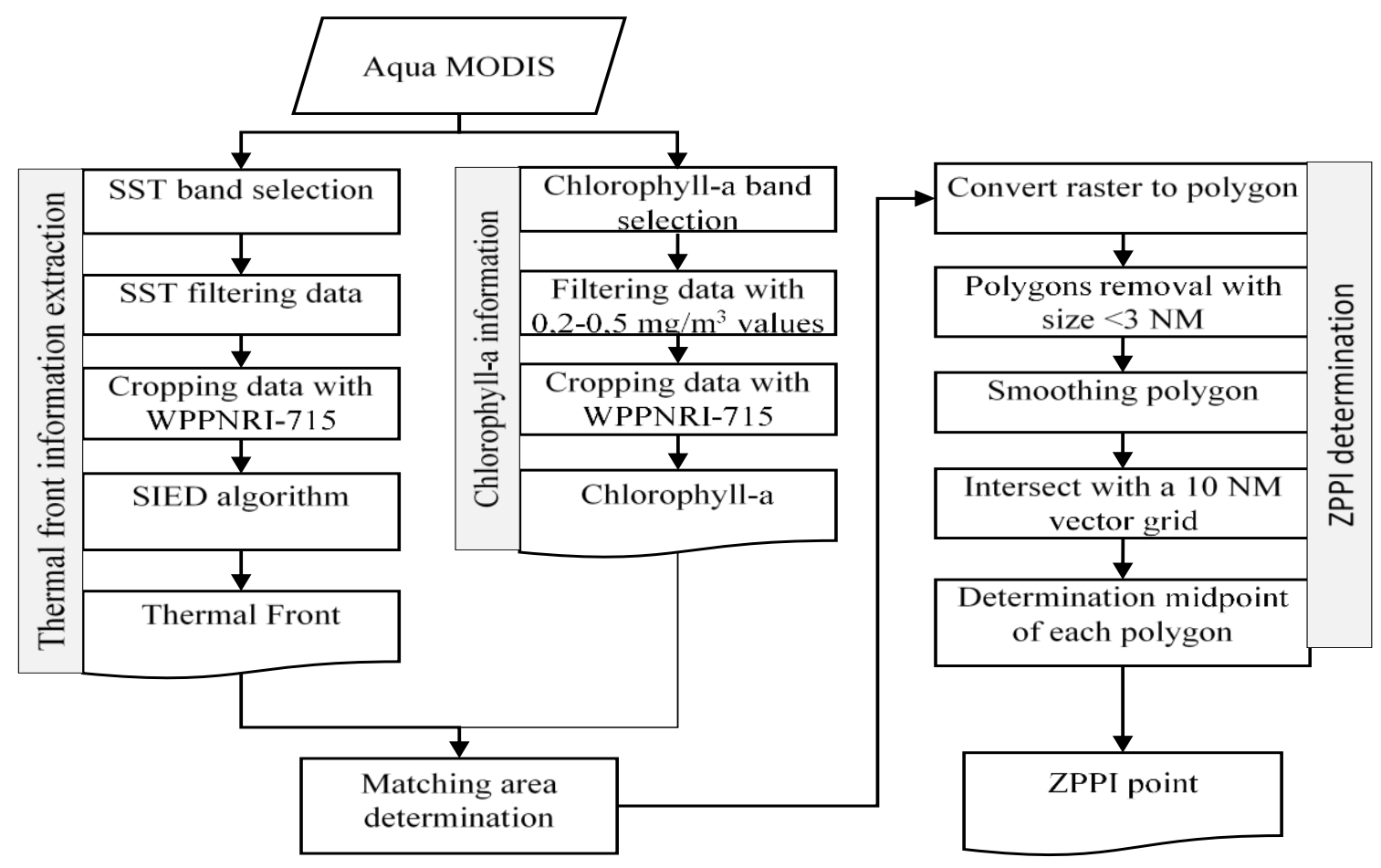

Figure 2. Flow chart of ZPPI point determination based on thermal front and mesotrophic area. 
Sea surface temperature is carried out on the GEE platform which consists of several stages, including selecting data (filtering), making the SST average value, cropping with the study area, and determining of thermal front with SIED algorithm. Data selection is carried out by selecting the SST band and filtering based on the required date. Thermal front detection with the SIED algorithm used a gradient threshold of $0.5^{\circ} \mathrm{C}$ as temperature difference which is an ideal threshold to be applied in Banda sea and surroundings (Hanintyo et al., 2015; Jatisworo \& Murdimanto, 2013) and have applied in Java sea and other Indonesian waters (Hamzah et al., 2014; Harsanugraha et al., 2014). This threshold is the average value of the temperature difference analyzed based on the results of the histogram calculation of several samples taken at random (Jatisworo \& Murdimanto, 2013). Aqua MODIS chlorophyll-a selected data is in the value range $0.2-0.5 \mathrm{mg} / \mathrm{m}^{3}$, which is a mesotrophic area that has water fertility related to food and potential fishing zones (Nurdin et al., 2017). The chlorophylla data filter was carried out by GEE using the mathematical expression feature.

After the thermal front and chlorophyll-a data obtained, further analysis carried out to get ZPPI points. The analysis is carried out by ArcMap software which consists of converting raster data to polygons, removal of small size polygons (< $3 \mathrm{~nm}$ ), edges smoothing (smoothing). These steps are done to make more accessible data which will intersect with fishnet grids. The fishnet grid is required to allow users to join spatial data into cells. Fishnet grid size is designed by considering length and radius of the gill net (the fishing gear used by mostly Indonesian fisherman) there are $10-18 \mathrm{~km} \mathrm{( \pm}$ 10 NM) (Hamzah et al., 2016).

The intersected data is the matching area between thermal front and chlorophyll-a with range number $0.2-0.5 \mathrm{mg} / \mathrm{m}^{3}$ and divided into cells by fishing net. ZPPI point can obtain from this data by determining the centroid points to determine the centroid coordinates of thermal front polygon. Centroid points of the polygon were implemented in kinds of research in remote sensing there are on land surface temperature by Sun et al. (2012), centroid of the aquaculture area to utilize the changes of spatial distribution by Kang et al. (2019), centroid of the islands affected by coastline changes by Zhang \& Hou (2020).

The centroid points used in this research were calculated by the geometric center of the polygons in ArcGIS 10.8 based on the equation by Bourke (1988). To calculate the value of the centroid points, first, calculate the area of an object to be calculated using equation 1 .

$$
A=\frac{1}{2} \sum_{i=0}^{n-1}\left(x_{i} y_{i+1}-x_{i+1} y_{1}\right) \ldots \ldots \ldots \ldots .
$$

Centroid coordinates from $\mathrm{n}$ values polygon can be determined using equation 2 (Bourke, 1988):

$C x=\frac{1}{6 A} \sum_{i=0}^{n-1}\left(x_{i}+x_{i+1}\right)\left(x_{i} y_{i+1}-x_{i+1} y_{i}\right)$

$$
C y=\frac{1}{6 A} \sum_{i=0}^{n-1}\left(y_{i}+y_{i+1}\right)\left(x_{i} y_{i+1}-x_{i+1} y_{i}\right)
$$

Information: $A$ was the area of an object, $C x$ was centroid coordinates based on the $\mathrm{x}$-axis, $C y$ was centroid coordinates based on the yaxis, $x$ was Coordinate $\mathrm{x}$, and $y$ was Coordinate $y$.

This long and complicated calculation can be done easily by employing the spatial model available in ArcMap, model builder. Model builder is an automation task feature in ArcMap that can map a repetitive workflow and involve multiple jobs at once (ESRI, 2018). Figure 3 describes the model builder from the ZPPI point calculation. In the model builder, "P" icons are responsible for the input file which implemented as a model parameter. 


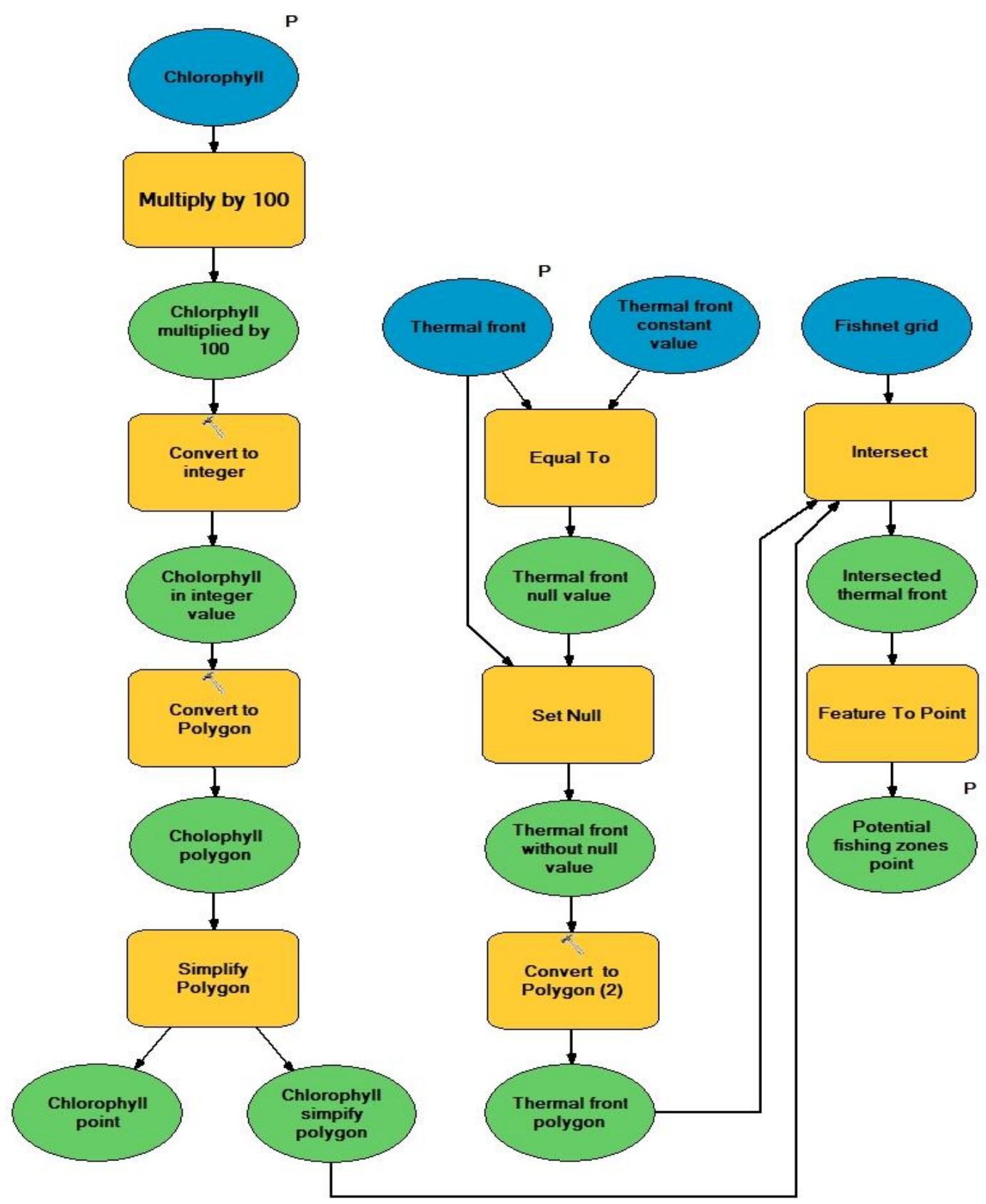

Figure 3. Flow chart of ZPPI model builder from the thermal front and chlorophyll-a data.

\section{RESULTS AND DISCUSSION}

\subsection{Results}

\subsubsection{Thermal Front and Mesotrophic Area}

Thermal front is detected from sea surface temperature data which has a significant temperature difference, in this study, $0.5^{\circ} \mathrm{C}$ is used as a threshold to identify the thermal front. So, if there is a temperature difference of more than equal to $0.5^{\circ} \mathrm{C}$, will be detected as a thermal front. The crosssection of thermal front sample from the analysis (Figure 4b) shows that there is a temperature difference of $0.6^{\circ} \mathrm{C}$ so that thermal front is identified in the area. The red feature (Figure 4a) is the thermal front, the black line is the cross-section of sea surface temperature (SST) and the other is sea surface temperature concentration. 


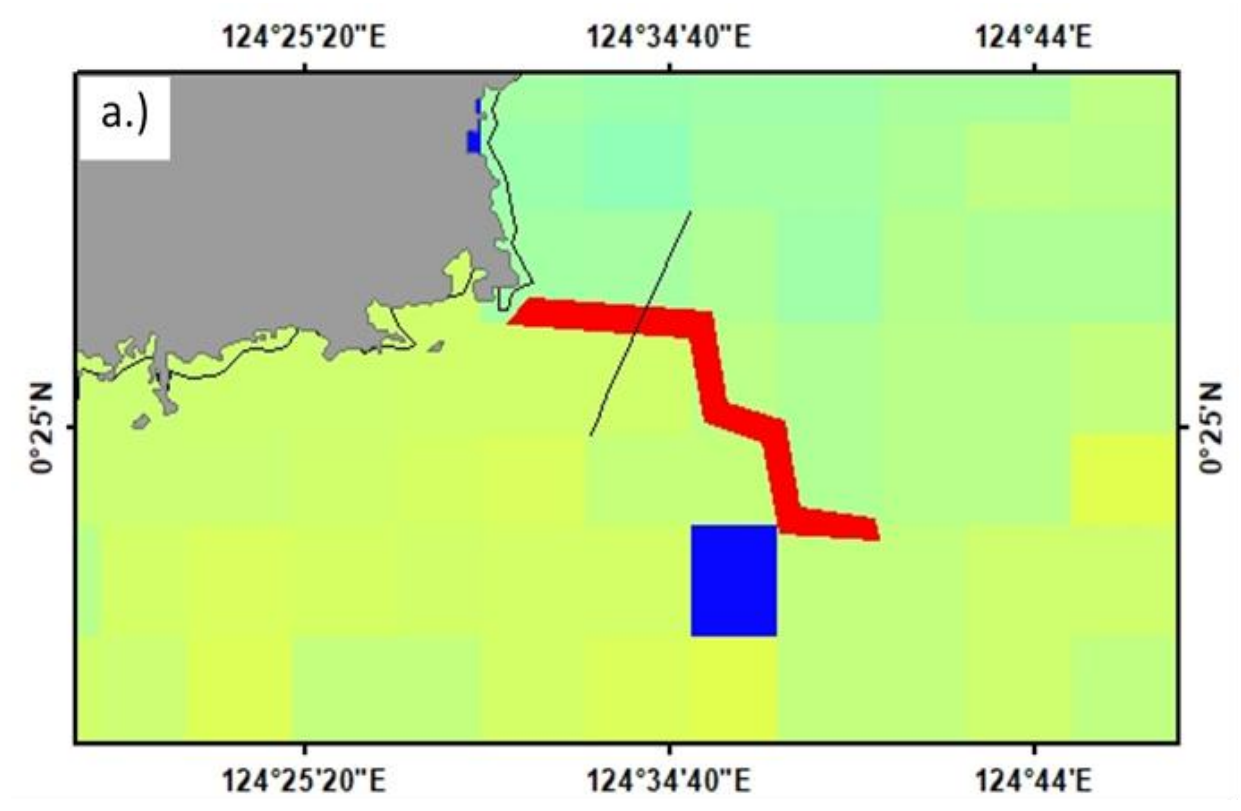

b.) Thermal Front Cross-section

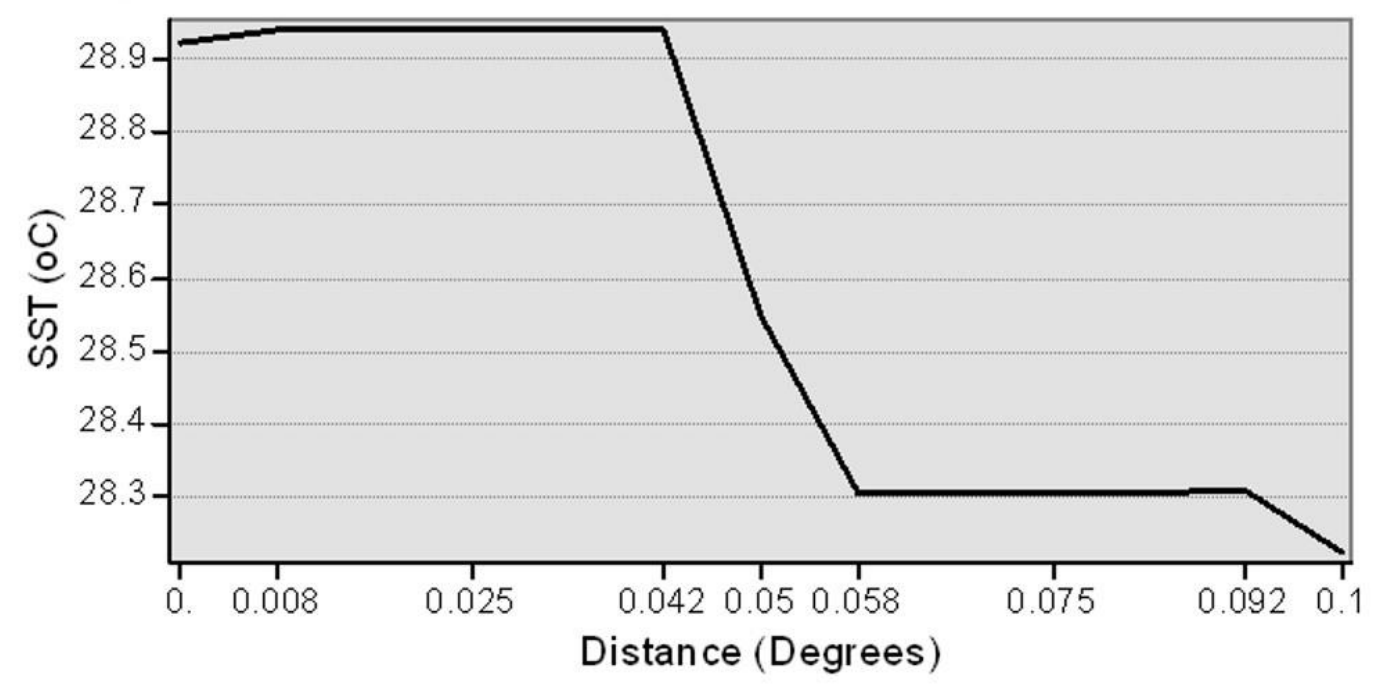

Figure 4. Thermal front profile a) thermal front cross-section (red line: thermal front, black line: cross-section line), b) thermal front cross-section graphic profile.

Thermal front and the mesotrophic area (described with chlorophyll-a data) distribution have the same tendency, which depends on cloud cover (Figures 5 and 6). The information from these parameters has not filtered with coastal areas. The results show thermal front and mesotrophic areas distributed both on open water and coastal area, so this is possible to produce ZPPI in both open water and coastal region. SST and chlorophyll-a data from Aqua MODIS imagery in GEE have $500 \mathrm{~m}$ spatial resolution with a day repeat time so that they are sufficient to be used in PFZ analysis. The results of Figures 5 and 6 show the distribution of thermal and chlorophyll-a fronts in the western monsoon, in which the spatial distribution is almost the whole study area of the highest number of thermal fronts (Table 1). 

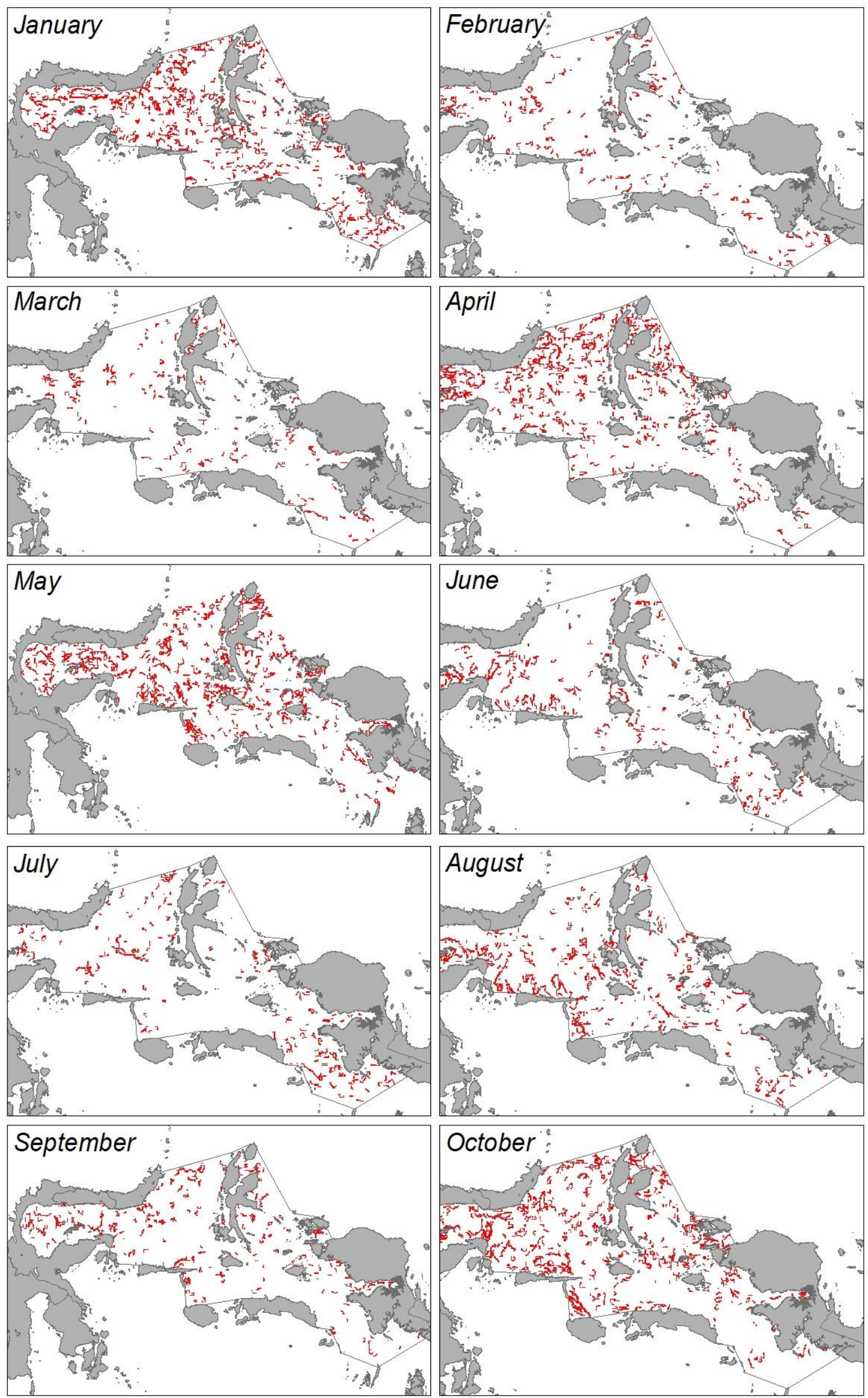

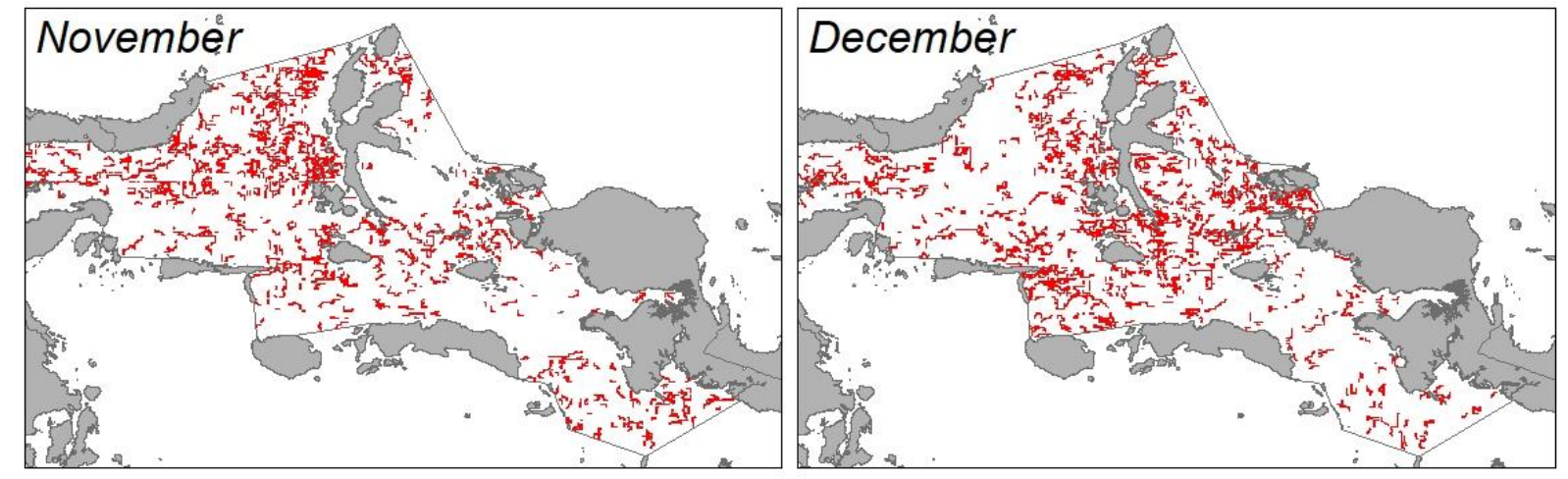

Figure 5. Thermal front distribution in WPPNRI 715 in 2018.
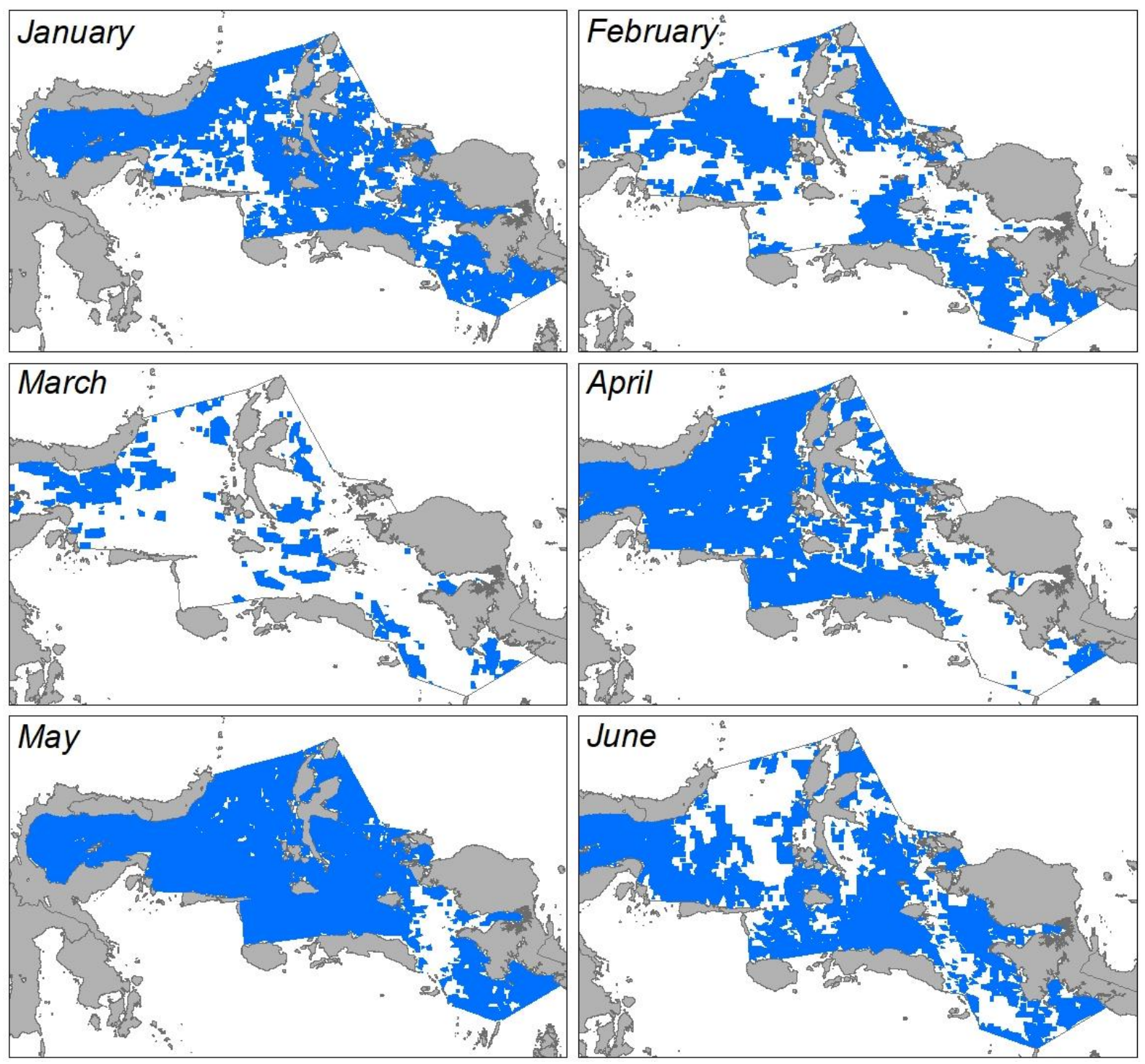

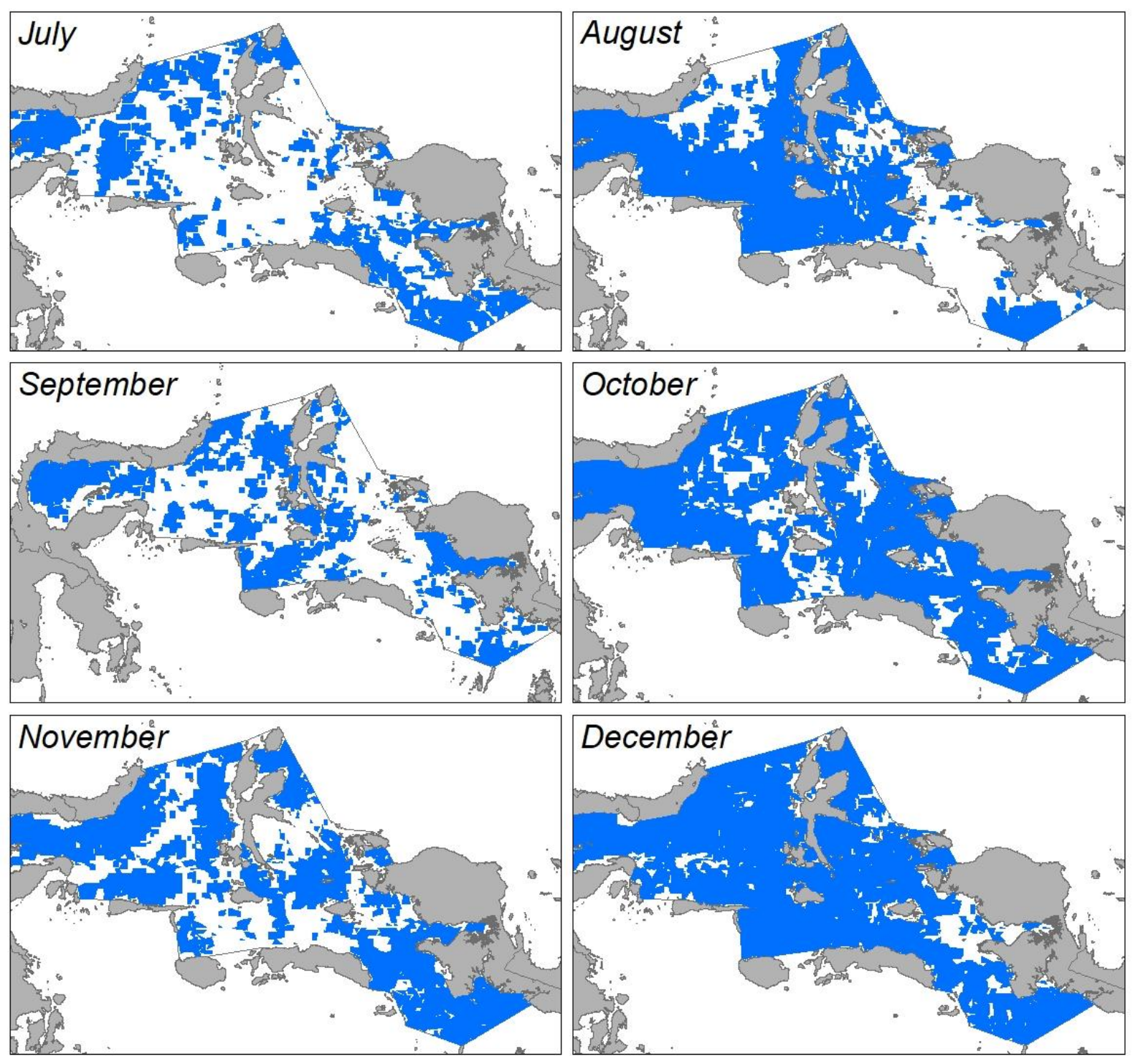

Figure 6. Mesotrophic area distribution on WPPNRI 715 in 2018.

The thermal front on WPPNRI 715 has a unique spatial distribution where the distribution is strongly influenced by the change of seasons. In the transition season II and the west season, the distribution is evenly distributed within the WPP area, including the Maluku Sea, Halmahera Sea, to the Banda Sea alternately, both in the coastal areas and the high seas. Transition season I, the increase in the distribution of thermal fronts between months, then decreases again in June (east season) until gradually increasing until December (west season).
Mesotrophic area distribution on WPPNRI 715 has a pattern that is almost the same as the thermal front event where the reduction of the distribution area occurs at each change of season, from west to transition I as well as a transition I to the east until the east season towards transition II.

\subsubsection{Model Simulation}

In this simulation, thermal front and mesotrophic area analysis results that have been obtained will be carried out in the process of determining the location of fish 
(ZPPI) based on the overlay of the two phenomena (Figure 7). The process requires satellite image data with data conditions in the same period to obtain consistent results. The matching area between the thermal front and mesotrophic area obtained by the intersect tool in ArcMap (Figure 7b). The intersect process requires input data in the form of a grid the size of $10 \mathrm{NM}$, which is based on the common area and fishing gear of Indonesian fishermen (Hamzah et al., 2016). The intersected thermal front will have a polygon cut limit each on a $10 \mathrm{NM}$ grid where will be determined the center value of each polygon (centroid coordinates) which is the ZPPI points (Figure 7c).

The intersected process between thermal front with the mesotrophic area will depreciate the number of thermal fronts. The comparison between the number of thermal fronts before and after intersected is shown in Table 1, the fluctuation between them shown in Table 1. It can see that the number of thermal fronts after the selection has decreased fluctuating, which is quite high in March $78.8 \%$. The average fell the number of thermal fronts during the period is 6471 pixels or $39.7 \%$.
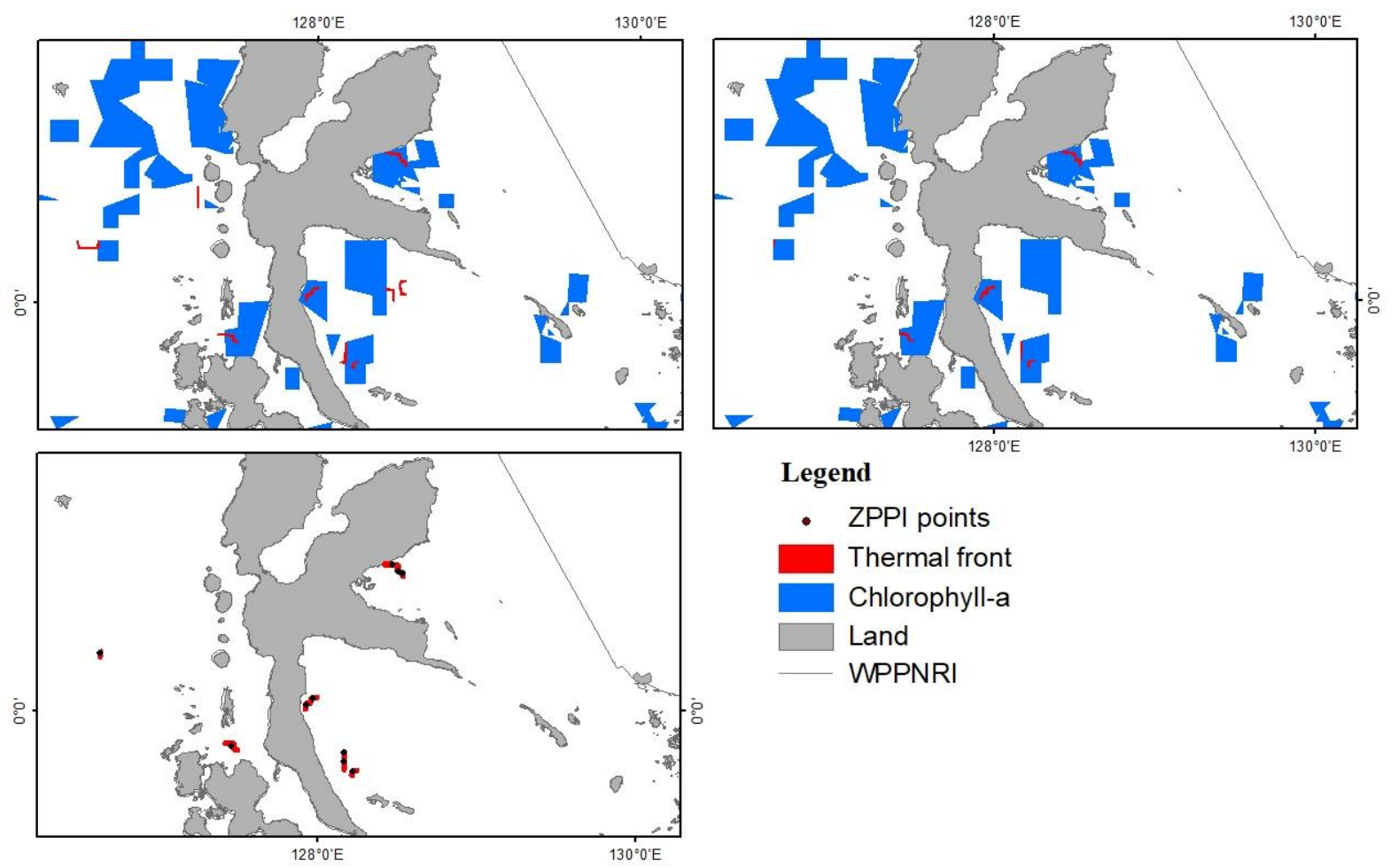

Legend

- ZPPI points

Thermal front

Chlorophyll-a

Land

- WPPNRI

Figure 7. ZPPI points determination simulation a) Thermal front and mesotrophic area overlay b.), Matching thermal front in mesotrophic area, c.) ZPPI point based on matching area between the thermal front and mesotrophic area.

Table 1. Comparison of the number of thermal fronts before and after intersected.

\begin{tabular}{lcccccccccccc}
\hline Date & Jan & Feb & Mar & Apr & May & Jun & Jul & Aug & Sep & Oct & Nov & Dec \\
\hline $\begin{array}{l}\text { Before } \\
\text { intersected }\end{array}$ & 1775 & 673 & 472 & 1508 & 1870 & 839 & 651 & 1150 & 732 & 1734 & 2183 & 2699 \\
$\begin{array}{l}\text { After } \\
\text { intersected }\end{array}$ & 980 & 408 & 372 & 993 & 1052 & 498 & 357 & 652 & 535 & 1072 & 1358 & 1538 \\
Depreciation & 795 & 265 & 100 & 515 & 818 & 341 & 294 & 498 & 197 & 662 & 825 & 1161 \\
\hline
\end{tabular}




\subsubsection{ZPPI Implementation}

The spatial distribution of monthly ZPPI points during the period is shown in Figure 8. ZPPI only from thermal front displayed with black points (before intersected) while the blue displayed ZPPI from the matching area between thermal front and mesotrophic area (after intersected). The intersect process can emit thermal front outside of the mesotrophic area. This ZPPI information can be classified as two-class, there are ZPPI with High Confident Level (High CL) which is blue points and the black points is ZPPI Moderate
Confident Level (Moderate CL). Although ZPPI High CL is the result of the intersected thermal front with the mesotrophic area, the number of ZPPI High CL each month has fluctuation as high as the Moderate CL (Figure 9.). ZPPI high CL has $34.07 \%$ less amount compared to ZPPI moderate CL. Both ZPPI CL distribution has a peak in December where it is in the west season. ZPPI has a valley in the transitional period between two seasons, this condition is in line with the distributions of thermal front and mesotrophic area in WPPNRI 715.
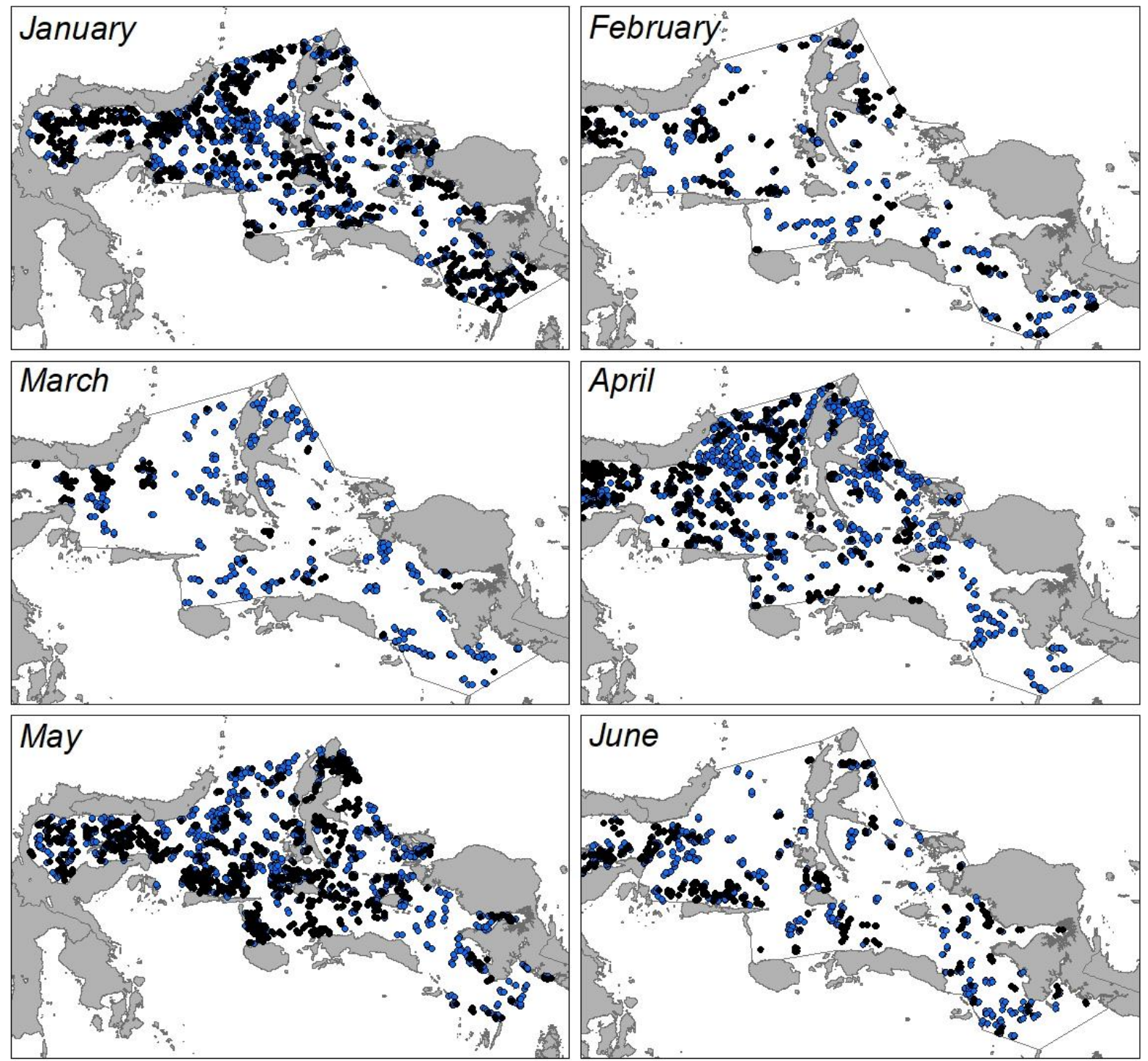

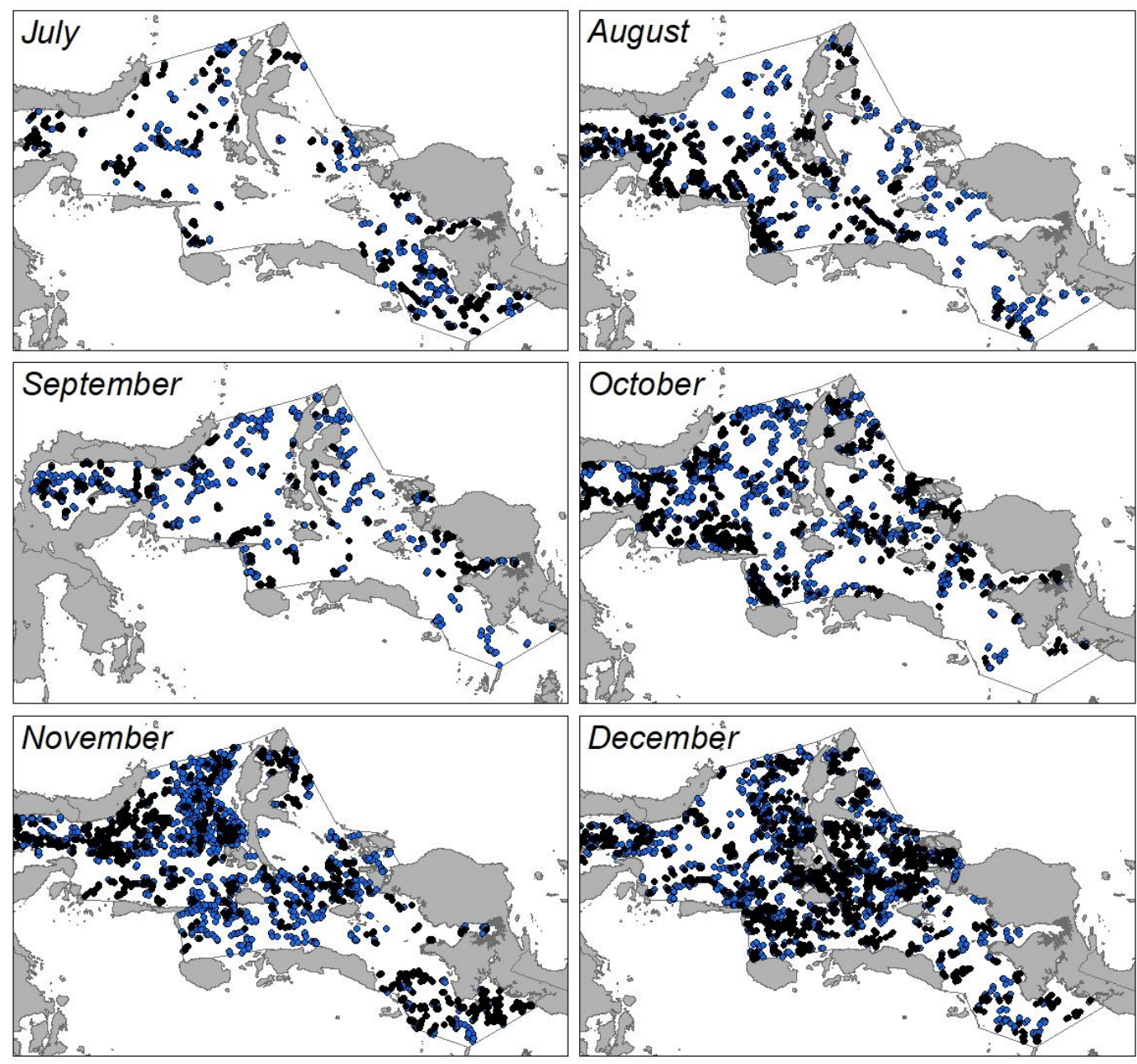

Figure 8. Spatial distribution of ZPPI points in 2018 (black for ZPPI from thermal front and blue for ZPPI from the matching area between thermal front and mesotrophic area).

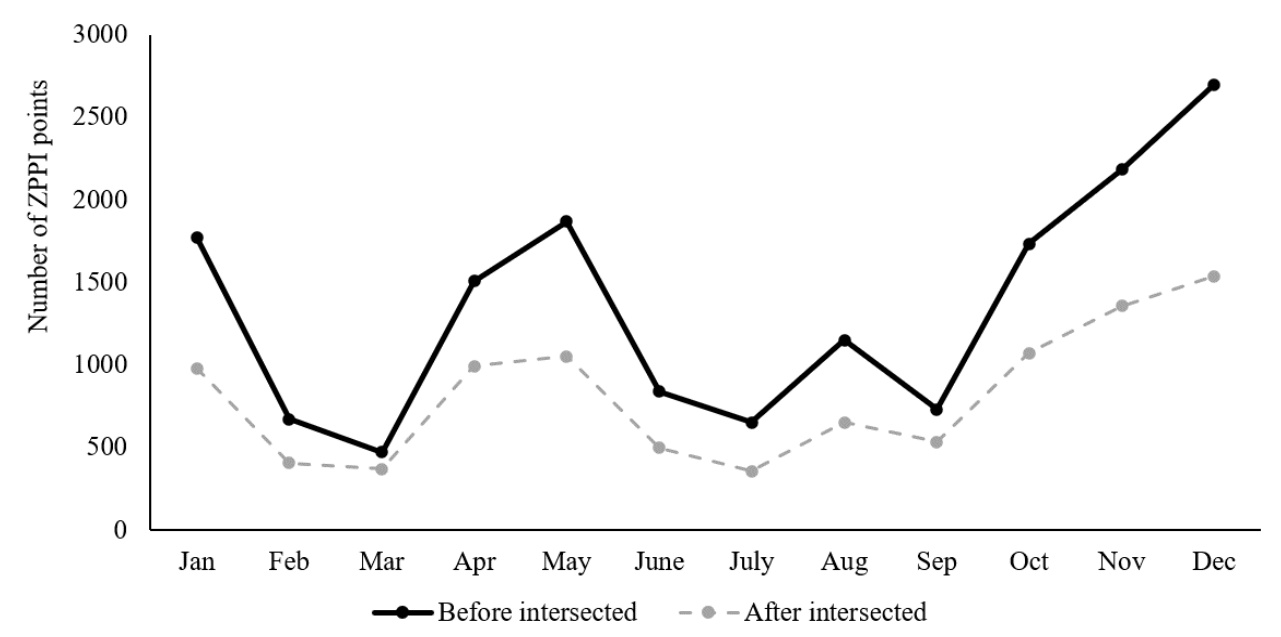

Figure 9. Graphic comparison between the number of ZPPI based on thermal front (Before intersected) and ZPPI based on matching area thermal front and mesotrophic area (after intersected). 


\subsection{Discussion}

This study proposes a new approach to determining the location of potential fishing zones (ZPPI) based on the matching area between thermal front and mesotrophic areas. These parameters are the most influential in predicting habitat areas of pelagic fish. The determination of ZPPI High $\mathrm{CL}$ is based on the location of the thermal front which occurs in the same location with the mesotrophic area. The mesotrophic area in Indonesian water was studied by Zainuddin et al. (2006), Zainuddin (2011), and Nurdin et al. (2017) in Sulawesi waters. The chlorophyll-a concentration in mesotrophic areas especially in Sulawesi water and surrounding areas (WPPNRI 715) is described by chlorophyll-a concentration between $0.2-0.5 \mathrm{mg} / \mathrm{m}^{3}$ where this area has moderate biological productivity and quite a water quality.

The proposed method in this paper is based on Sholva et al. (2013) who use contour matching to find upwelling and thermal front. The development from the last method is in the form of a matching area and parameter selection used.

This paper generates ZPPI information which can be classified as 2 class, there are ZPPI with High Confident Level (High CL) and ZPPI Moderate Confident Level (Moderate CL). The high confidence level can be defined because based on the research of Harsanugraha et al. (2014) the accuracy of moderate CL reaches $80.5 \%$ but it is still on a wide scale of catching area that is 10 and 20 miles so that with the results of research Nurdin et al., 2017 which proves the condition of the mesotrophic area in Sulawesi waters becomes a habitat for pelagic fish, especially Rastrelliger kanagurta is expected by using these two parameters in getting the High CL ZPPI, it can improve the accuracy of the existing ZPPI.

The matched area between thermal front and chlorophyll-a makes decreasing the number of thermal fronts. A $39.7 \%$ decrease was experienced by the thermal front during the study. This condition can be tolerated because more than $50 \%$ of the location of the thermal front is still maintained. Besides, ZPPI information using Aqua MODIS data from GEE, and this method can provide ZPPI not only on the high sea but also on the coast is still being covered.

The parameters used are based on the compared results to in-situ fish catch data by the last research. This approach is believed to improve the accuracy of fishing zones because in predicting the location of fish that needs to be understood is the behavior of fish related to the habitat favored by fish. The accuracy of improvement could not perform because of the limited availability of fish catch data. Future studies are expected to measure the accuracy of ZPPI High CL information using comparison with the fish catch from in-situ data.

\section{CONCLUSION}

Based on this research can be concluded that thermal fronts and chlorophyll-a can be generated automatically using the Google Earth Engine platform which doesn't require high computer specifications. The method can provide ZPPI High Confident Level (High CL) which generate from the matching area between thermal front and mesotrophic area. The matching area will decrease thermal front information until $39.7 \%$ depends on cloud cover. Increased accuracy of ZPPI information will be achieved on the coast and the high sea can be done by using a fish behavior approach where thermal front and mesotrophic area are the dominant parameters affecting the presence of fish.

\section{ACKNOWLEDGMENTS}

This research was funded by the budget of DIPA LAPAN activities in 2019, Remote Sensing Application Center, Indonesian National Institute of Aeronautics 
and Space (LAPAN). Thanks to going to RSAC LAPAN which has supported the implementation of this research, especially to Dr. M. Rokhis Khomarudin as the Director who has supported research and development activity. Aqua MODIS images were provided by NASA Goddard Space Flight Center, Ocean Ecology Laboratory, Ocean Biology Processing Group in Google Earth Engine. We thank anonymous reviewers. Argo Galih Suhadha contributed to making concept, analyzing, processing, and modeling the potential fishing zones, and Wikanti Asriningrum contributed in discussion and writing check.

\section{REFERENCES}

Bourke, P. 1988. Calculating the area and centroid of a polygon.

http://local.wasp.uwa.edu.au/ pbourke /geometry/lineline/polyarea/.

[Retrieved on November 1, 2019]

Cayula, J. \& P. Cornillon. 1992. Edge detection algorithm for SST images. J. Atmospheric and Oceanic Technology, 9(1): 67-80. https://doi.org/10.1175/15200426(1992)009<0067:EDAFSI>2.0.C $\mathrm{O} ; 2$

Chang, Y. \& P. Cornillon. 2015. A comparison of satellite-derived sea surface temperature fronts using two edge detection algorithms. Deep-Dea Research Part II: Topical Studies in Oceanography, 119(1): 40-47. https://doi.org/10.1016/j.dsr2.2013.12 .001

El-Serehy, H.A., H.S. Abdallah, F.A. AlMisned, S.A. Al-Farraj, \& K.A. AlRasheid. 2018. Assessing water quality and classifying trophic status for scientifically based managing the water resources of the Lake Timsah, the lake with salinity stratification along the Suez Canal Saudi. J. Biol. Sci., 25(1): 1247-1256. https://doi.org/10.1016/j.sjbs.2018. 05.022

ESRI. 2018. Melakukan automasi tugas dengan model builder.

https://community.esri.com/groups/ arcnesia/blog/2018/02/07/melakuka n-automasi-tugas-dengan-modelbuilder. [Retrieved on October 1, 2019]

Gorelick, N., M. Hancher, M. Dixon, S. Ilyushenchenko, D. Thau, \& R. Moore. 2017. Google Earth Engine: Planetary-scale geospatial analysis for everyone. Remote Sensing of Environment, 202(1): 18-17. https://doi.org/10.1016/j.rse.2017.0 6.031

Lumban-Gaol, J., R.R. Leben, S. Vignudelli, K. Mahapatra, Y. Okada, B. Nababan, M. Mei-Ling, K. Amri, R.E. Arhatin, \& M. Syahdan. 2015. Variability of satellite-derived sea surface height anomaly, and its relationship with Bigeye tuna (Thunnus obesus) catch in the Eastern Indian Ocean. European J. of Remote Sensing, 48(1): 465-477. https://doi.org/10.5721/EuJRS2015 4826

Gordon, A.L., A. Ffield, \& A.G. Ilahude. 1994. Thermocline of the Flores and Banda Seas. J. of Geophysical Research, 99(C9): 18235-18242. http://doi.org/10.1029/94jc01434

Hamzah, R., T. Prayogo, \& W.K. Harsanugraha. 2014. Identifikasi thermal front dari data satelit Terra/Aqua MODIS menggunakan metode Single Image Edge Detection (SIED) (Studi kasus: Perairan utara dan selatan Pulau Jawa). In: Kartasasmita et al. (eds.). Prosiding Seminar Nasional Penginderaan Jauh 2014, IPB International Convention Center, Bogor, 21 April 2014. 552-559 pp. 
Hamzah, R., T. Prayogo, \& S. Marpaung. 2016. Metode penentuan titik koordinat zona potensi penangkapan ikan pelagis berdasarkan hasil deteksi termal front suhu permukaan laut. $J$. Penginderaan Jauh, 13(2): 97-108. http://doi.org/10.30536/j.pjpdcd.2016. v13.a2364

Hanintyo, R., S. Hadianti, R.M.P. Mahardhika, A.J. Saputra, \& F. Islamy. 2015. Sebaran musiman kejadian thermal front berdasarkan citra Aqua- MODIS di WPP-RI 715, 715, WPP-RI 716. In: Sambodo et al. (eds.). Prosiding Seminar Nasional Penginderaan Jauh 2015, IPB International Convention Center, Bogor, 11-12 November 2015. 523$635 \mathrm{pp}$.

Harsanugraha, W.K., T. Prayogo, S. Marpaung, R. Hamzah, B. Hasyim, G. Sitanggang, \& A. Supriyono S.W. 2014. Pemanfaatan data satelit NPP dan Altimetri untuk penentuan Zona Potensi Penangkapan Ikan. Lembaga Penerbangan dan Antariksa Nasional. Jakarta. 97 p.

Iskandar, I., W. Mardiansyah, D.O. Lestari, \& Y. Masumoto. 2020. What did determine the warming trend in the Indonesian sea?. Prog. Earth Planet Sci, 7(20): 1-11.

https://doi.org/10.1186/s40645-02000334-2

Jatisworo, D. \& A. Murdimanto. 2013. Identifikasi thermal front di Selat Makassar dan Laut Banda. In: Wicaksono, P. et al. (eds.). Simposium Nasional Sains Geoinformasi III, University Club, Universitas Gadjah Mada, Yogyakarta, 25-26 September 2013. 226-232 pp.

Jishad, M., R.K. Sarangi, S. Ratheesh, S.M. Ali, \& R. Sharma. 2019. Tracking fishing ground parameters in cloudy region using ocean colour and satellite-derived surface flow estimates: A study in the Bay of Bengal. J. of Operational Oceanography, 12(1): 1-12. https://doi.org/10.1080/1755876X.20 19.1658566

Kang, J., L. Sui, X. Yang, Y. Liu, Z. Wang, J. Wang, F. Yang, B. Liu, \& Y. Ma. 2019. Sea surface-visible aquaculture spatial-temporal distribution remote sensing: a case study in Liaoning Province, China from 2000 to 2018. Sustainability, 11(24): 1-23. https://doi.org/10.3390/su11247186 Nurdin, S., M.A. Mustapha, T. Lihan, \& M. Zainuddin. 2017. Applicability of remote sensing oceanographic data in the detection of potential fishing grounds of Rastrelliger kanagurta in the archipelagic waters of Spermonde, Indonesia. Fisheries Research, 196(1): 1-12. https://doi.org/10.1016/j.fishres.201 7.07.029

Podestá, G.P., J.A. Browder, \& J.J. Hoey. 1993. Exploring the association between swordfish catch rates and thermal fronts on U.S. longline grounds in the Western North Atlantic. Continental Shelf Research, 13(2-3): 253-277. https://doi.org/10.1016/02784343(93)90109-B

Reese, D.C., R.T. O’Malley, R.D. Brodeur, \& J.H. Churnside. 2011. Epipelagic fish distributions in relation to thermal fronts in a coastal upwelling system using highresolution techniques. ICES J. of Marine Science, 68(9): 1865-1874. https://doi.org/10.1093/icesjms/fsr1 07

Rustini, H.A., E. Harsono, \& I. Ridwansyah. 2018. Potential area for floating net fishery in Lake Toba. IOP Conf. Ser: Earth Environ. Sci. 118(1): 1-7. 
https://doi.org/10.1088/1755-

1315/118/1/012032

Syah, A.F., L.W. Ramdani, \& K.I. Suniada. 2020. Prediction of potential fishing zones for mackerel tuna (Euthynnus sp) in Bali strait using remotely sensed data. IOP Conf. Ser.: Earth Environ. Sc, 500(1): 1-11. https://doi.org/10.1088/17551315/500/1/012070

Sholva Y., B. Sitohang, \& K. Wikantika. 2013. New approach to locate upwelling and thermal-front from satellite imagery data. Procedia Technology, 11(1): 317-326. http://doi.org/10.1016/j.protcy.2013.1 2.197

Sun, Q., Z. Wu, \& J. Tan. 2012. The relationship between land surface temperature and land use/land cover in Guangzhou, China. Environ. Earth Sci., 65(6): 1687-1694. https://doi.org/10.1007/s12665-0111145-2

Suman, E., Wudianto, B. Sumiono, H.E. Irianto, Badrudin, \& K. Amri. 2014. Potensi dan tingkat pemanfaatan sumberdaya ikan di Wilayah Pengelolaan Perikanan Republik Indonesia (WPP RI). Ref Grafika, Jakarta. 224 p.

Wen, Z., K. Song, L. Lyu, C. Fang, Y. Shang, G. Liu, \& J. Du. 2020. A national-scale data set for dissolved carbon and its spatial pattern in lakes and reservoirs across China. Sci. Data, 7(82): 1-10.

https://doi.org/10.1038/s41597-0200419-5

Wijesekera, H.W., E. Shroyer, A. Tandon, M. Ravichandran, D. Sengupta, S.
Jinadasa, H.J. Fernando, N. Agrawal, K. Arulananthan, \& G. Bhat. 2016. ASIRI: an oceanatmosphere initiative for Bay of Bengal. American Meteorological Society, 97(10): 1859-1884. https://doi.org/10.1175/BAMS-D14-00197.1

Wyrtki, K. 1961. Physical oceanography of the southeast asian waters. NAGA REPORT. California. 195 p. https://doi.org/10.1001/archneur.19 94.00540230067015

Zainuddin, M., H. Kiyofuji, K. Saitoh, \& S.I. Saitoh. 2006. Using multisensor satellite remote sensing and catch data to detect ocean hot spots for Albacore (Thunnus alalunga) in the Northwestern North Pacific. DEEP-SEA RESEARCH Part II, 53(3-4): 419-431. http://doi.org/10.1016/j.dsr2.2006.0 1.007

Zainuddin, M. 2011. Skipjack tuna in relation to sea surface temperature and chlorophyll-a concentration of Bone Bay using remotely sensed satellite data. J. Ilmu dan Teknologi Kelautan Tropis, 3(1): 82-90. http://doi.org/10.29244/jitkt.v3i783 7

Zhang, Y. \& X. Hou. 2020. Characteristics of coastline changes on southeast Asia islands from 2000 to 2015. Remote Sensing, 12(3): 1-22. https://doi.org/10.3390/rs12030519

Received : 30 December 2019

Reviewed : 17 July 2020

Accepted : 21 August 2020 
